\title{
GLL
}

00 Geomatics, Landmanagement and Landscape No. $2 \cdot 2021,101-119$

\section{ANALYSIS OF LAND USE CHANGES IN THE TRI-CITY METROPOLITAN AREA BASED ON THE MULTI-TEMPORAL CLASSIFICATION OF LANDSAT AND RAPIDEYE IMAGERY}

\author{
Bogusława Kwoczyńska
}

\section{Summary}

The aim of the study was to diagnose the main trends of land cover changes around urban agglomerations over the last twenty years (1997-2016) on the example of Tri-City, and to present them statistically and graphically in the form of compilation of numerical maps. The research was performed on the basis of remotely sensed data: LANDSAT 5 TM satellite imagery from 1997 and RapidEye from two records $(2011,2016)$.

The metropolises of Gdańsk, Gdynia and Sopot, constituting the core of metropolitan area (MA), and municipalities belonging to the Tri-City MA located in its vicinity were selected for detailed analyses - the inner zone of 2 communes and the outer zone, also of 2 communes (MA outskirts). In the selected metropolitan area, communes with good and poor natural conditions for agricultural production were studied.

The analyses were performed on processed images (colour compositions), which were subjected to supervised classification with the maximum likelihood technique. The quality control of supervised classification showed an accuracy of $87.2 \%$ for LANDSAT 5 TM scene analyses and $93.8 \%$ for RapidEye imagery. The Kappa coefficient for the discussed classification was, respectively: 0.85 (LANDSATTM) and 0.93 (RapidEye).

The conducted analyses showed that in the communes there were changes in the way of using arable land and grassland. The greatest changes took place in communes with a low Agricultural Production Space Valuation Ratio (APSVR). Grassland, and to a lesser extent areas with scattered development, replaced arable land. In Gdańsk, Sopot and Gdynia, belonging to the TriCity, the greatest changes over 20 years took place in arable land, which altogether diminished by $17 \%$, and forest land (13\% in total). All this to the benefit of grassland (increase by $23 \%$ ) and built-up areas (10\% in total in all cities).

\section{Keywords}

land use $\bullet$ satellite imagery $\bullet$ metropolitan area

\section{Introduction}

Land cover refers to the physical properties of the earth's surface captured during the arrangement of vegetation, water, soil, or artificial structures. By contrast, land use refers to the way land has been or is used by humans and their habitats, usually 
with an emphasis on the functional role of land for economic activities. Land cover/ use is a composite term that covers both land cover and land use categories. Land cover/use provides information about changes that play an important role in local and regional planning as well as on a macro-level planning. In most cases, environmental planning and management tasks are cumbersome due to insufficient information on land cover/land use change indicators. Land cover changes are naturally progressive and gradual but can sometimes be rapid and sudden due to anthropogenic activity [Butenuth et al. 2007].

For years, obtaining the necessary information about the cover or use of areas has been based on satellite imagery of different terrain resolution. An example is images such as Landsat TM and ETM + [Meliadis 2005, Meliadis et al. 2005, Comber et al. 2016]. This approach has many advantages:

1) a synoptic view of large geographic areas;

2) a digital form of data facilitating more efficient analyses;

3) land cover maps can be generated at a much lower cost than others.

However, the Landsat terrain resolution $(30 \mathrm{~m})$ does not always allow to achieve the appropriate study accuracy. Therefore, more and more often in recent times, widely available free of charge imagery such as SENTINEL-2A or ESA and commercial satellite systems e.g., WorldView-2, DigitalGlobe or RapidEye are used.

The MOLAND (Monitoring Land Cover/Land Use Dynamics) project implemented by the EU's Joint Research Centre can serve as an example of the use of remote sensing images to monitor spatial transformations in urbanised areas. This programme was a continuation of the previously implemented (since 1998) MURBANDY (Monitoring Urban Dynamics) programme. The aim of the MOLAND programme was to assess, monitor and model the past, present and future development of cities and regions from the sustainable development point of view [Barredo et al. 2003].

Remotely sensed image data constitutes an objective record of a landscape, a comprehensive registration of its components and the relationships taking place between them, especially spatial ones [Mularz et al. 2007]. They have different cartometric and photo-interpretation potential, determined mainly by the character and resolution of the imaging, enabling them to be used to develop maps of land cover and land use at various scales and with varying degrees of detail of demarkings [Drzewiecki 2008]. In their studies, these topics were also discussed by [Grabowska 2017], [Schneider 2012], [Tewkesbury et al. 2015], [Tian et al. 2013], [Reihaneh Peiman 2011], [Lu et al. 2004], [Bruzzone 1997], [Zhu et al. 2014], [Cegielska et al. 2018].

The aim of this study was to diagnose the main trends of land cover changes around urban agglomerations, with particular emphasis on arable land and grassland. The analyses were conducted on the example of selected communes of the Tri-City (Gdańsk, Gdynia, Sopot) over the period of twenty years (1997-2016).

The research results were presented with the use of graphical (compilation of numerical maps), tabular (statistical summaries) and descriptive methods. The project was based on remotely sensed data: RapidEye and LANDSAT TM satellite imagery. 


\section{Remote sensing methods used to analyse land use changes}

The development of remote sensing techniques, in particular the increase in the temporal and spatial resolution of remote sensing images, made it possible to conduct both detailed research on small areas and the creation of global studies of changes in land cover and land use. In places where these changes occur very quickly, they can be observed in real time [Verburg et al. 2009], [Abburu and Golla 2015, Comber et al. 2016].

In remote sensing studies, land cover is observed and on its basis the use is concluded. Thus, legends are constructed in which specific areas fit both concepts, comparing in a given class a specific type of land cover corresponding to its use. These types of legends are widely used in research, the subject of which is referred to as Land Use/Land Cover [Civco et al. 2002, Chen et al. 2003, Cakir et al. 2006, Vieira et al. 2012, Hermosilla et al. 2018].

Over the years, remote sensing has been used to map land use/land cover in different parts of India [Gautam and Narayanan 1983, Sharma et al. 1984, Jain 1992, Brahabhatt et al. 2000]. It made it possible to study land cover changes in less time, at lower cost and with greater accuracy. The remote sensing and geographic information system (GIS) provide efficient methods for analysing land use issues and tools for land use planning and modelling.

Multi-temporal remote sensing images are not only a highly effective tool to monitor the changes taking place on the Earth's surface but also, as studies conducted as part of the MOLAND programme show, they can also provide data necessary to build advanced models supporting spatial policy on a local, national and European scale [Busko and Szafrańska 2018].

There are Europe-wide Earth monitoring programmes, including GMES (Global Monitoring for Environment and Security). GMES is an initiative of the European Union, implemented jointly by the European Commission and the European Space Agency, the aim of which was to support the implementation of the sustainable development policy [Michałowska and Głowienka-Mikrut 2010]. The implementation of the programme began with the initiation of the so-called Fast Track Services (FTS) concerning three application areas: land surface monitoring, sea monitoring and extraordinary environmental threats [Prakasam 2010]. The programme, the implementation of which was started as part of the fast track for the so-called continental component, is a continuation of the CORINE Land Cover programme.

The results of the work of such programmes are atlases that show changes taking place in selected European cities [Bochenek 2004]. The study of land cover and land use changes based on multi-time remote sensing images has been performed for many years both in Poland and abroad [Krischke 2000, Lu 2004, Ciołkosz and Poławski 2006, Verburg et al. 2009, Sandau 2010, Loveland and Dwyer 2012, Markham and Helder 2012, Wulder et al. 2012, Wężyk et al. 2013, Xu et al. 2018].

In their publication, Lu et al. [2004] reviewed the methods of detecting changes based on satellite imagery. They divided the methods into seven general groups: alge- 
braic methods, transformations, classifications, models, application of geographic information systems, visual analyses and other approaches [Zhu 2017].

The method used in this study, the supervised classification using the "Maximum Likelihood" technique [Hejmanowska et al. 2020], belongs to one of them, and the research concerns the area of northern Poland, i.e., the Tri-City metropolitan area (MA).

\section{Research methodology}

\subsection{Source data}

Nowadays, the basic source of information about the environment, and at the same time about the changes taking place in it, is satellite imagery. When examining changes in land cover, the most important advantages of satellite images are: synopticity, high repeatability of imaging the same areas, relatively low acquisition cost and automation of the process of interpreting their content [Ciołkosz and Poławski 2006, Hermosilla et al. 2018]. A very important and invaluable factor that may affect the use of this data is its availability. The Landsat mission has been providing data about the Earth continuously for forty years. All archival and up-to-date images are available to any user worldwide, free of charge. Sensory Thematic Mapper and Enhanced Thematic Mapper Plus located on satellites moving in a heliosynchronous orbit are the source of multispectral images with a field resolution of $30 \mathrm{~m}$ [Yuan et al. 2005, Niedzielko and Lewiński 2012, Vogelmann et al. 2016, Wulder et al. 2016, Zhu 2017].

The work uses source materials divided into three periods, i.e., set A: including LANDSAT 5 TM (Thematic Mapper; NASA) satellite scenes from 1997; set B: RapidEye images from 2011; and set C: RapidEye images from 2016.

The Landsat system was launched on July 23, 1972, when the first satellite was launched to an altitude of $920 \mathrm{~km}$ above the Earth. The satellite moves in a circular heliosynchronous orbit. The RBV (Return Beam Vidicon) imaging camera and the Multispectral Scanner System (MSS) have been installed on board satellites 1, 2 and 3. The disadvantage of this system is its accuracy, which makes detailed analysis impossible. In 2013, a new satellite was sent into orbit, which allows for the creation of images with slightly higher accuracy. In Landsat 8 , it is 15 meters per pixel.

The LANDSAT TM data was chosen because of their 40-year uninterrupted sequence of observations and availability [Loveland and Dwyer 2012, Markham and Helder 2012, Wulder et al. 2012, Hermosilla et al. 2018]. When selecting the images, 5 basic criteria were adopted, i.e.: the registration period in April-November (sets A, $\mathrm{B}$ and C); cloud cover for a single scene no greater than $20 \%$; field resolution $<30.0 \mathrm{~m}$; radiometric resolution: 8-bit; spectral resolution: minimum 4 channels [Wężyk et al. 2013]. These images were pre-processed.

Set B and C (images from 2011 and 2016) included multispectral satellite images of the RapidEye commercial system, which is characterised by a constellation of five satellites located at an altitude of $630 \mathrm{~km}$, placed in a heliosynchronous orbit moving at 19-minute intervals, imaging in 5 spectral channels $(\mathrm{RGB}+2 \mathrm{xNIR})$ with a spatial 
resolution of $5.0 \mathrm{~m}$ [Krischke et al. 2000, Sandau et al. 2010]. This is a new system compared to Landsat. It was launched into orbit on August 29, 2008. One of the biggest advantages of the system is a wide recording band and a high resolution of 5 meters per pixel, which gives 3 times better quality compared to the latest version of Landsat (Landsat 8).

The images obtained in this way were used for the land use/land cover (LULC) classification of the Tri-City and its neighbouring communes as of 2016. Digital orthophotos with a spatial resolution of $0.25 \mathrm{~m}$ and current as of 2016 were also obtained for the studied area. The orthophotos were used to improve the quality of RapidEye satellite image classification (2011 and 2016) [Kwoczyńska et al. 2019].

\subsection{Characteristics of the research object}

The selection of the metropolises was related to the territorial scope of the project under which a broader research on the sustainable development of selected metropolitan areas in Poland was conducted. In the scope of the project 2016/21/D/ HS4/00264 entitled Urban agriculture as a challenge to the sustainable development of metropolitan areas in Poland, economic, social, environmental and planning aspects have been limited to selected metropolitan areas of Poland, which are understood as "the area of a large city and its direct surroundings functionally related to it, established in the concept of spatial development of the country" [KPZK 2030]. As part of this project, 5 metropolitan areas were analysed: a large one - Warsaw, mediumsized ones - Kraków, Tri-City and Wrocław, and a small one - Lublin. These areas were also selected taking into account the location, so that they represent the area of southern, central, northern, eastern and western Poland. This made it possible to take into account the large diversity of individual parts of the country, as differences in the level of agricultural development that are visible to this day have their source in distant historical events.

The analysis of land use changes in selected communes of the Lublin metropolitan area based on remote sensing data was presented in the publication [Kwoczyńska et al. 2019], while the above publication presents analyses for selected communes of the Tri-City (Gdańsk, Gdynia, Sopot). The distribution of selected metropolises in Poland is shown in Figure 1a, and the distribution of communes within the Tri-City MA in Figure $1 \mathrm{~b}$ and $\mathrm{c}$.

The analyses covered selected communes of the Tri-City metropolitan area (MA), which include the communes: Kosakowo, Stegna, Nowy Dwór Gdański and Sulęczyno, as well as the cities of Gdańsk, Gdynia, Sopot, constituting the Tri-City, and at the same time the core of the metropolitan area (MA). The total area of these zones is $975.65 \mathrm{~km}^{2}$, and the number of inhabitants is approximately 800,000 .

The communes for the analysis were selected in accordance with the scope of sustainable development. The Tri-City is the core of the analysis, Kosakowo and Stegna belong to the inner ring surrounding the MA (metropolitan area) and the outer ring are the remaining communes: Nowy Dwór Gdański and Sulęczyno. The 

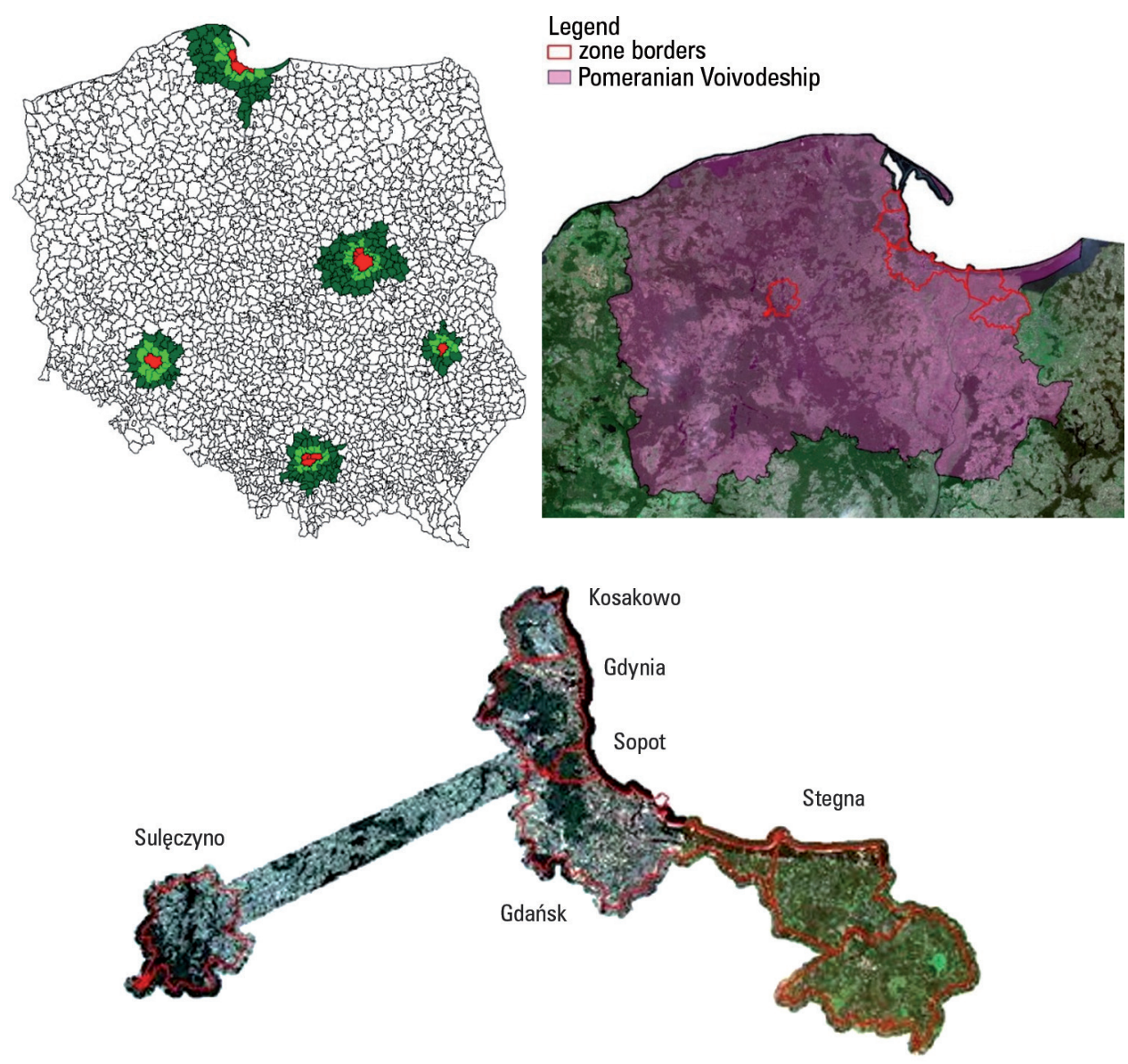

Nowy Dwór Gdański

Fig. 1. Distribution of: a) selected metropolitan areas (MA) in Poland; b) communes of the Tri-City MA in the Pomeranian Voivodeship, c) communes in relation to the Tri-City

commune of Nowy Dwór Gdański and Stegna are communes with a high APSVR (Agricultural Production Space Valuation Ratio), while Kosakowo and Sulęczyno have a low APSVR (Fig. 2).

For each of the selected municipalities, the condition and changes (1997-2016) of the land use structure (forests, agricultural land, grassland, wasteland, water) were assessed, and the expansion of buildings (compact and dispersed development) to agricultural areas was analysed. 


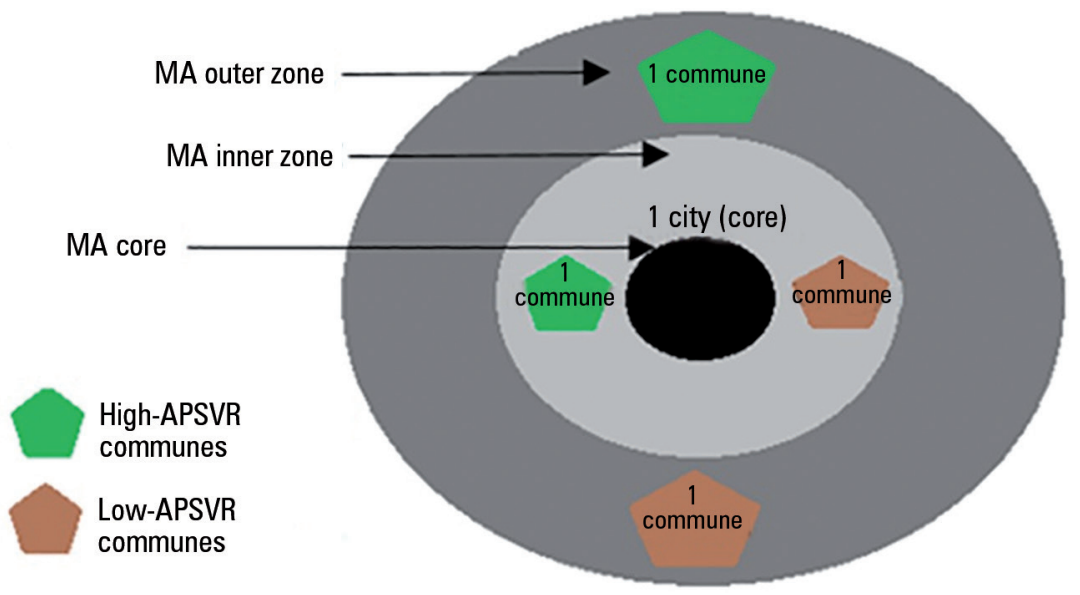

Fig. 2. Distribution of communes within the metropolitan area

\subsection{Processing of remote sensing images}

In order to obtain information on land use in the analysed time periods and the studied communes, Landsat and RapidEye images were digitally classified, but firstly, on the basis of appropriately selected spectral channels, the following colour compositions were created for them:

- For the 1997 Landsat imagery, the composition (452) was prepared, which best reflected the data of the utility structure

- For the 2011 RapidEye images, the following compositions were prepared: (123), (135), (243), of which the composition (123) was selected for further research,

- For the 2016 RapidEye images, the following compositions were prepared: (345), (213), (423), of which composition (423) was selected for supervised classification.

Figures 3-5 show the colour compositions used.

For the analysis included in the study, the classification supervised with the use of the "Maximum Likelihood" technique was used. The application of this method was reported by [Bałazy et al. 2013], [Oliveira Duarte 2016], while Li and Yeh [1998] in: Lu D. et al. [2004] used the supervised maximum-likelihood classification to detect land cover changes in the Pearl River Delta area in China.

In the first phase, supervised classification consists in selecting the so-called training fields on the basis of which the class patterns are created, i.e., similarly to the unsupervised method: class measures and ranges. Detailed image statistics are calculated for training fields (e.g., DN values: average, minimum, maximum, standard deviation, variance). In the next phase, pixels are assigned to user-defined classes (e.g., forest, water, buildings) using various classification algorithms. This process is called super- 
1997 Landsat imagery

Composition 452

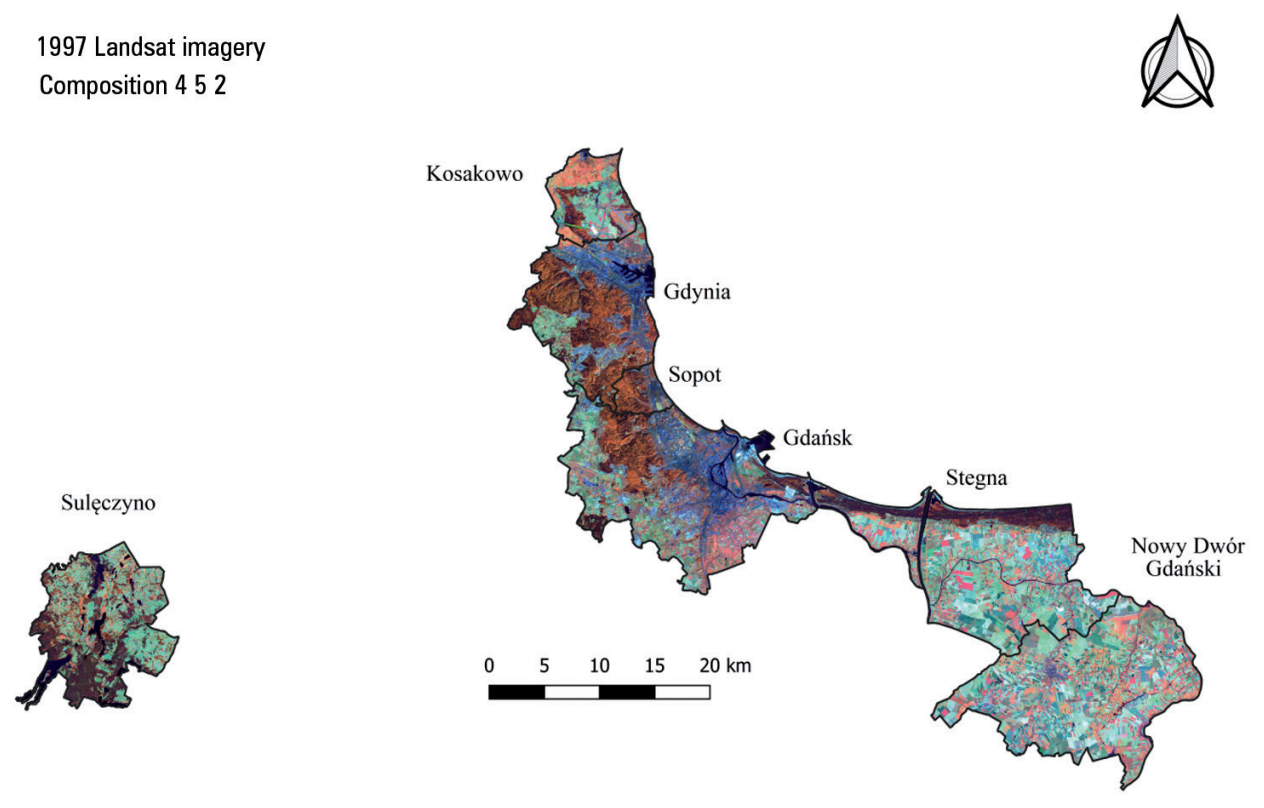

Fig. 3. The (452) colour composition based on a Landsat images from 1997

2011 RapidEye imagery

Composition 123

Fig. 3. The (452) colour composition based on a Landsat images from 1997

\section{Composition 123}

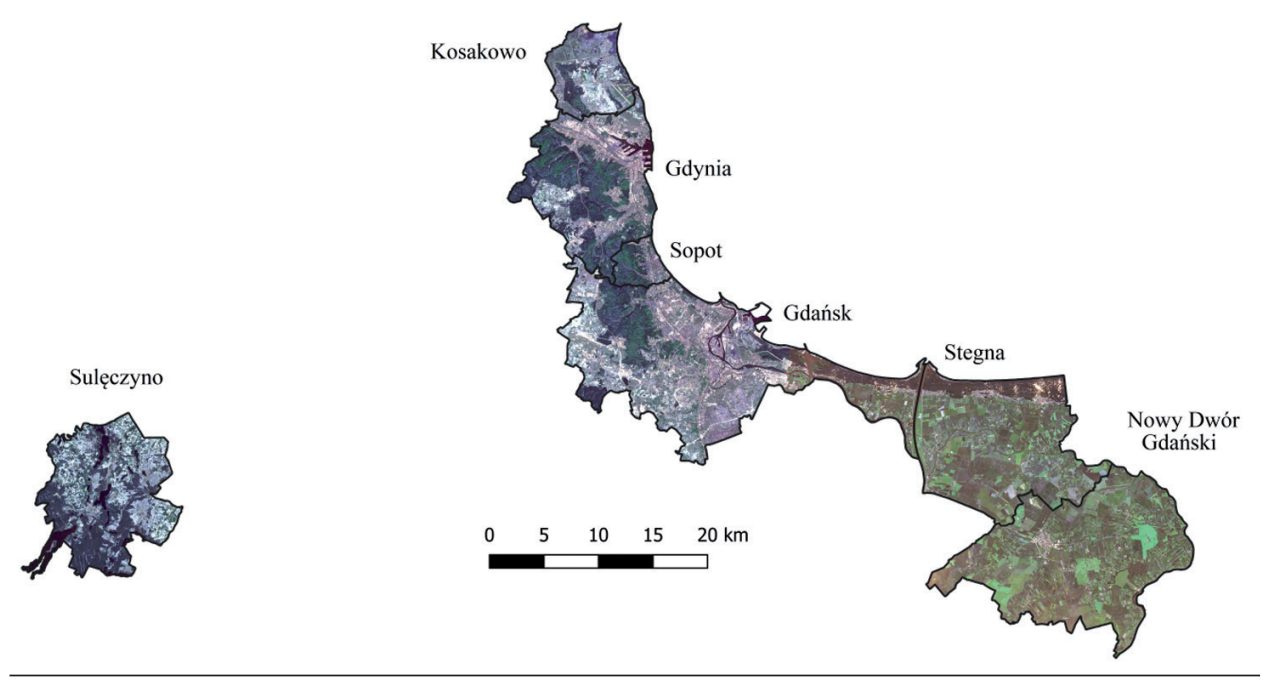

Fig. 4. The (123) colour composition based on a RapidEye images from 2011 

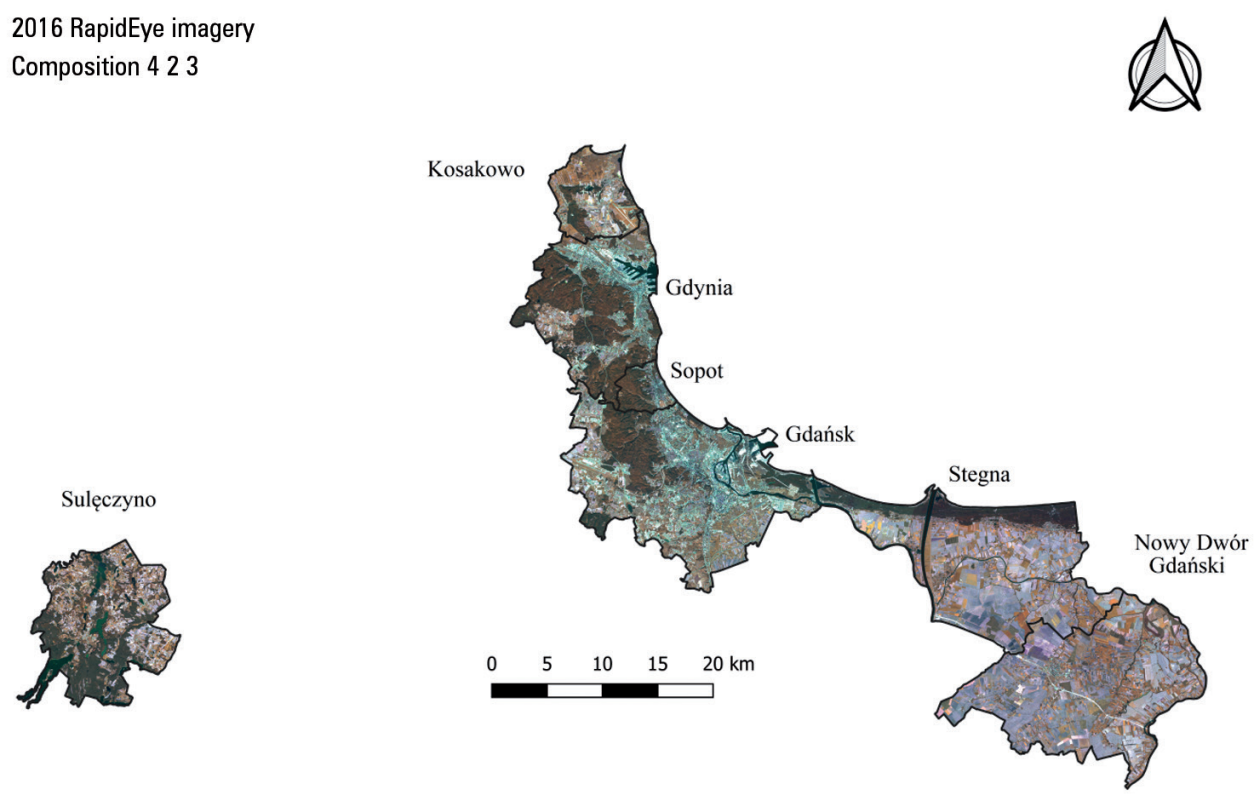

Fig. 5. The (423) colour composition based on a RapidEye images from 2016

vised classification because the user has full control over the entire process. The last stage is the analysis of the reliability of the classification, which is carried out using a set of test fields (also called control plots) similar to the training fields, but determined independently from them [Hejmanowska and Wężyk 2020].

In remote sensing, the following algorithms have been used for supervised classification for many years: the parallelepiped, the minimum distance and the maximum probability methods. Relatively new methods used for image classification are: random forests, support vectors and deep learning.

The Maximum Likelihood Classification (MLC) is a method based on calculating the probability that each pixel belongs to a specific class. The pixel is assigned to a class with the highest probability of belonging. The method assumes that the pattern statistics used to calculate the probability value of belonging to a given class are normally distributed. The method provides the most accurate results among the methods mentioned, but it is the most computationally demanding [Hejmanowska and Wężyk 2020].

As mentioned above, the maximum likelihood technique was selected for the classification of the research areas and its accuracy was assessed. As a result of the conducted classification, 6 classes of land cover and land use were obtained for three research dates (1997, 2011 and 2016), i.e., forests, grassland, arable land, urbanized areas (compact and scattered development) and water. The result of the work are the obtained land use maps for individual research dates and communes of the Tri-City MA (Fig. 6-8). 
1997 Landsat imagery

Supervised classification
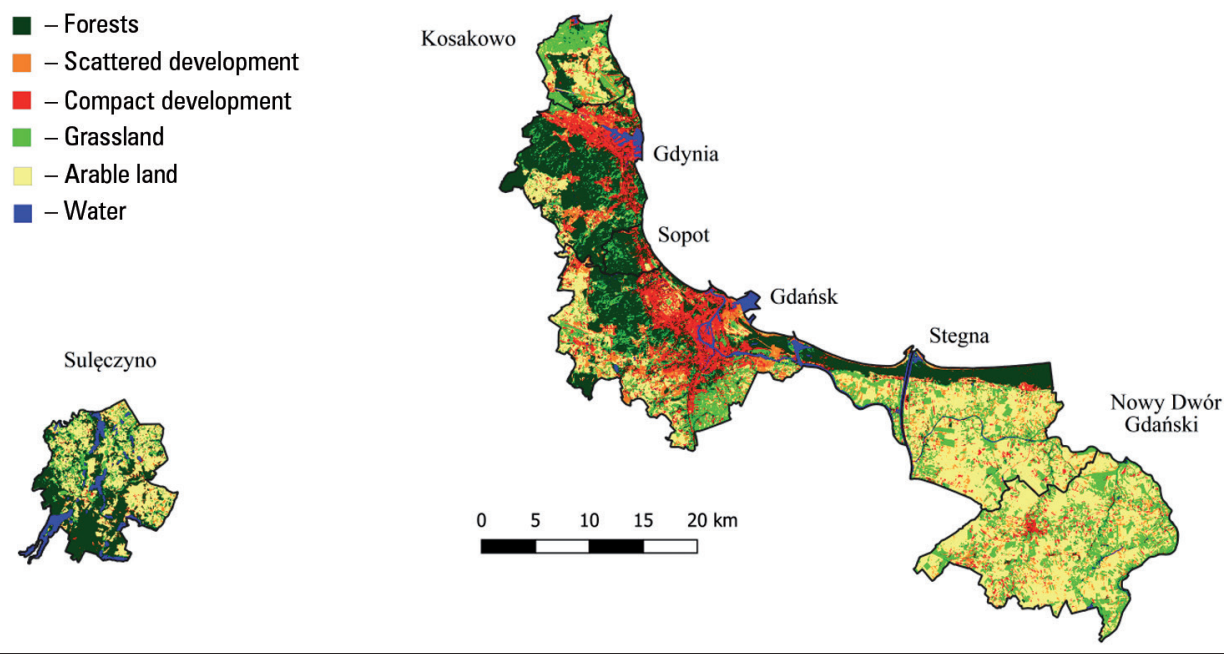

Fig. 6. Map of land use in the Tri-City MA drawn up on the basis of the Landsat image from 1997

2011 RapidEye imagery

Supervised classification

- Forests

- Scattered development

- Compact development

- Grassland

- Arable land

- Water
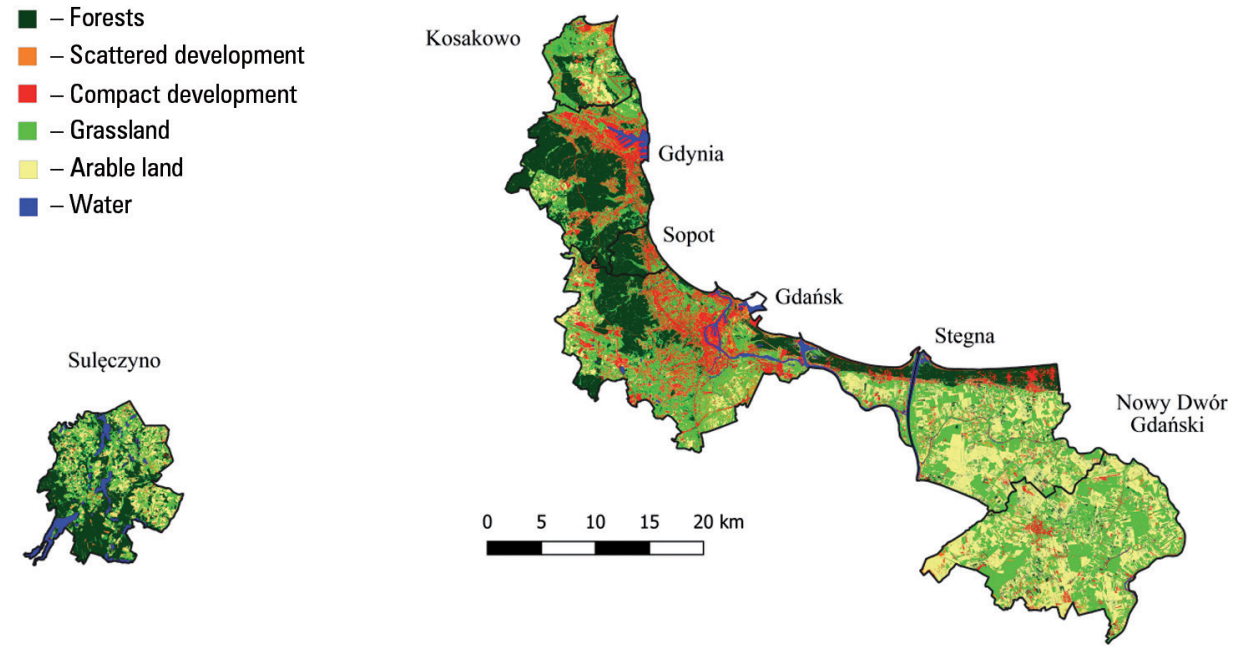

Fig. 7. Map of land use in the Tri-City MA drawn up on the basis of the RapidEye image from 2011 
2016 RapidEye imagery

Supervised classification
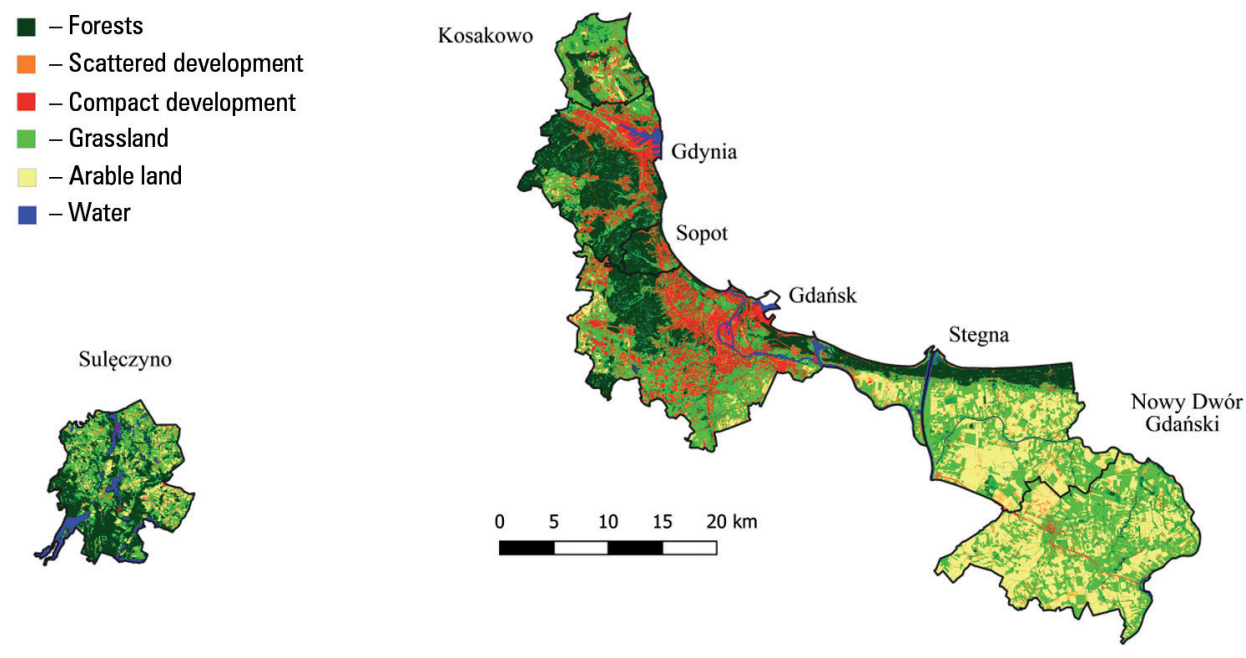

Fig. 8. Map of land use in the Tri-City MA drawn up on the basis of the RapidEye image from 2016

On the basis of the error matrix, parameters describing the classification accuracy were determined. The performed quality control of supervised classification showed an accuracy of $87.2 \%$ for LANDSAT 5 TM scene analyses and $93.8 \%$ for RapidEye imagery. The Kappa coefficient for the discussed classification was, respectively: 0.85 (LANDSATTM) and 0.93 (RapidEye).

\section{Research results and discussion}

The basic assumption in the adopted method of examining changes was to perform independent classification of satellite images for each registration date, using the same set of land cover classes, and to compare the classification images. The accuracy of distinguishing individual land cover classes directly affects the precision of determining change areas. Therefore, it is extremely important to use such a classification method that would ensure the classification of the satellite image with the highest possible accuracy. In the presented study, it was the maximum likelihood method [Kwoczyńska et al. 2019].

The comparison of the obtained land use maps of the surveyed areas from individual time periods allowed for the determination of changes in the land use structure both in the Tri-City and the neighbouring communes over 20 years. Detailed lists of the percentage share of each class of land in the total area of the surveyed communes and the Tri-City in the analysed time intervals are presented in Tables 1-3. 
Table 1. Percentage breakdown of individual land use classes (LULC) in each commune of the Tri-City MA, made on the basis of Landsat imagery

\begin{tabular}{|c|c|c|c|c|c|c|c|}
\hline & & & & 1997 L & ddsat imagery & & \\
\hline & LULC & $\begin{array}{c}\text { Forests } \\
{[\%]}\end{array}$ & $\begin{array}{c}\text { Grassland } \\
{[\%]}\end{array}$ & $\begin{array}{c}\text { Arable } \\
\text { land } \\
\text { [\%] }\end{array}$ & $\begin{array}{c}\text { Dispersed } \\
\text { development } \\
{[\%]}\end{array}$ & $\begin{array}{c}\text { Compact } \\
\text { development } \\
{[\%]}\end{array}$ & $\begin{array}{l}\text { Water } \\
{[\%]}\end{array}$ \\
\hline & Gdańsk & 29.00 & 14.00 & 20.00 & 9.00 & 23.00 & 5.00 \\
\hline & Sopot & 69.00 & 8.00 & 4.00 & 3.00 & 16.00 & 0.00 \\
\hline & Gdynia & 53.00 & 8.00 & 11.00 & 4.00 & 21.00 & 3.00 \\
\hline$\$$ & $\begin{array}{l}\text { Commune of } \\
\text { Stegna }\end{array}$ & 14.00 & 17.00 & 55.00 & 4.00 & 8.00 & 2.00 \\
\hline$\stackrel{\substack{0 \\
.1}}{.1}$ & $\begin{array}{l}\text { Commune of } \\
\text { Kosakowo }\end{array}$ & 26.00 & 19.00 & 36.00 & 7.00 & 11.00 & 1.00 \\
\hline & $\begin{array}{l}\text { Commune of } \\
\text { Nowy Dwór } \\
\text { Gdański }\end{array}$ & 7.00 & 23.00 & 60.00 & 6.00 & 4.00 & 0.00 \\
\hline & $\begin{array}{l}\text { Commune of } \\
\text { Sulęczyno }\end{array}$ & 41.00 & 8.00 & 36.00 & 2.00 & 4.00 & 9.00 \\
\hline
\end{tabular}

Table 2. Percentage breakdown of individual land use classes (LULC) in each commune of the Tri-City MA, made on the basis of RapidEye imagery from 2011

\begin{tabular}{|c|c|c|c|c|c|c|c|}
\hline & \multirow[b]{2}{*}{ LULC } & \multicolumn{6}{|c|}{2011 RapidEye imagery } \\
\hline & & $\begin{array}{c}\text { Forests } \\
{[\%]}\end{array}$ & $\begin{array}{c}\text { Grassland } \\
{[\%]}\end{array}$ & $\begin{array}{c}\text { Arable } \\
\text { land } \\
\text { [\%] }\end{array}$ & $\begin{array}{c}\text { Dispersed } \\
\text { development } \\
{[\%]}\end{array}$ & $\begin{array}{c}\text { Compact } \\
\text { development } \\
{[\%]}\end{array}$ & $\begin{array}{c}\text { Water } \\
\%]\end{array}$ \\
\hline \multirow{7}{*}{ 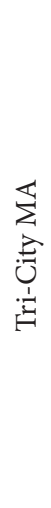 } & Gdańsk & 23.00 & 22.00 & 17.00 & 10.00 & 24.00 & 4.00 \\
\hline & Sopot & 64.00 & 10.00 & 3.00 & 6.00 & 17.00 & 0.00 \\
\hline & Gdynia & 52.00 & 11.00 & 8.00 & 5.00 & 21.00 & 3.00 \\
\hline & $\begin{array}{l}\text { Commune of } \\
\text { Stegna }\end{array}$ & 14.00 & 27.00 & 45.00 & 4.00 & 8.00 & 2.00 \\
\hline & $\begin{array}{l}\text { Commune of } \\
\text { Kosakowo }\end{array}$ & 24.00 & 34.00 & 23.00 & 8.00 & 11.00 & 0.00 \\
\hline & $\begin{array}{l}\text { Commune of } \\
\text { Nowy Dwór } \\
\text { Gdański }\end{array}$ & 6.00 & 33.00 & 49.00 & 6.00 & 6.00 & 0.00 \\
\hline & $\begin{array}{l}\text { Commune of } \\
\text { Sulęczyno }\end{array}$ & 44.00 & 19.00 & 21.00 & 4.00 & 4.00 & 8.00 \\
\hline
\end{tabular}


Table 3. Percentage breakdown of individual land use classes (LULC) in each commune of the Tri-City MA, made on the basis of RapidEye imagery from 2016

\begin{tabular}{|c|c|c|c|c|c|c|c|}
\hline \multirow{2}{*}{\multicolumn{2}{|c|}{ LULC }} & \multicolumn{6}{|c|}{2016 RapidEye imagery } \\
\hline & & $\begin{array}{c}\text { Forests } \\
{[\%]}\end{array}$ & $\begin{array}{c}\text { Grassland } \\
{[\%]}\end{array}$ & $\begin{array}{c}\text { Arable } \\
\text { land } \\
\text { [\%] }\end{array}$ & $\begin{array}{c}\text { Dispersed } \\
\text { development } \\
{[\%]}\end{array}$ & $\begin{array}{c}\text { Compact } \\
\text { development } \\
{[\%]}\end{array}$ & $\begin{array}{c}\text { Water } \\
{[\%]}\end{array}$ \\
\hline \multirow{7}{*}{ 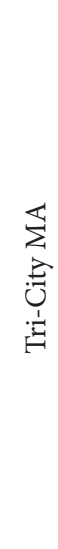 } & Gdańsk & 22.00 & 28.00 & 11.00 & 11.00 & 25.00 & 3.00 \\
\hline & Sopot & 63.00 & 11.00 & 3.00 & 6.00 & 17.00 & 0.00 \\
\hline & Gdynia & 53.00 & 14.00 & 4.00 & 5.00 & 22.00 & 2.00 \\
\hline & $\begin{array}{l}\text { Commune of } \\
\text { Stegna }\end{array}$ & 15.00 & 28.00 & 41.00 & 6.00 & 8.00 & 2.00 \\
\hline & $\begin{array}{l}\text { Commune of } \\
\text { Kosakowo }\end{array}$ & 22.00 & 47.00 & 10.00 & 9.00 & 12.00 & 0.00 \\
\hline & $\begin{array}{l}\text { Commune of } \\
\text { Nowy Dwór } \\
\text { Gdański }\end{array}$ & 5.00 & 36.00 & 46.00 & 7.00 & 6.00 & 0.00 \\
\hline & $\begin{array}{l}\text { Commune of } \\
\text { Sulęczyno }\end{array}$ & 45.00 & 26.00 & 10.00 & 4.00 & 4.00 & 7.00 \\
\hline
\end{tabular}

Changes in land use that took place in individual communes of the Tri-City metropolitan area between individual research periods are presented in Tables 4 and 5.

Table 4. Percentage breakdown of changes in land use for individual communes of the Tri-City MA made on the basis of 1997 Landsat - 2011 RapidEye imagery

\begin{tabular}{|l|c|c|c|c|c|c|c|}
\hline \multicolumn{7}{|c|}{1997 Landsat - 2011 RapidEye } \\
\hline Gdańsk & Sopot & Gdynia & Kosakowo & Stegna & Sulęczyno & $\begin{array}{c}\text { Nowy Dwór } \\
\text { Gdański }\end{array}$ \\
\hline Land & {$[\%]$} & {$[\%]$} & {$[\%]$} & {$[\%]$} & {$[\%]$} & {$[\%]$} & {$[\%]$} \\
\hline Forests & -6 & -5 & -1 & -2 & 0 & 3 & -1 \\
\hline $\begin{array}{l}\text { Dispersed } \\
\text { development }\end{array}$ & 1 & 3 & 1 & 1 & 0 & 2 & 0 \\
\hline $\begin{array}{l}\text { Compact } \\
\text { development }\end{array}$ & 1 & 1 & 0 & 0 & 0 & 0 & 2 \\
\hline Grassland & 8 & 2 & 3 & 15 & 10 & 11 & 10 \\
\hline Arable land & -3 & -1 & -3 & -13 & -10 & -15 & -11 \\
\hline Water & -1 & 0 & 0 & -1 & 0 & -1 & 0 \\
\hline
\end{tabular}


Table 5. Percentage breakdown of changes in land use for individual communes of the Tri-City MA made on the basis of 2011 RapidEye - 2016 RapidEye imagery

\begin{tabular}{|l|c|c|c|c|c|c|c|}
\hline \multicolumn{7}{|c|}{2011 RapidEye - 2016 RapidEye } \\
\hline Gdańsk & Sopot & Gdynia & Kosakowo & Stegna & Sulęczyno & $\begin{array}{c}\text { Nowy Dwór } \\
\text { Gdański }\end{array}$ \\
\hline Land & {$[\%]$} & {$[\%]$} & {$[\%]$} & {$[\%]$} & {$[\%]$} & {$[\%]$} & {$[\%]$} \\
\hline Forests & -1 & -1 & 1 & -2 & 1 & 1 & -1 \\
\hline $\begin{array}{l}\text { Dispersed } \\
\text { development }\end{array}$ & 1 & 0 & 0 & 1 & 2 & 0 & 1 \\
\hline $\begin{array}{l}\text { Compact } \\
\text { development }\end{array}$ & 1 & 0 & 1 & 1 & 0 & 0 & 0 \\
\hline Grassland & 6 & 1 & 3 & 13 & 1 & 7 & 3 \\
\hline Arable land & -6 & 0 & -4 & -13 & -4 & -7 & -3 \\
\hline Water & -1 & 0 & -1 & 0 & 0 & -1 & 0 \\
\hline
\end{tabular}

The changes that took place in the 20 -year period in the Tri-City metropolitan area are presented in Table 6 and graphically in Figure 9.

Table 6. Percentage breakdown of changes in land use for individual communes of the Tri-City MA made on the basis of 1997 Landsat - 2016 RapidEye imagery

\begin{tabular}{|l|c|c|c|c|c|c|c|}
\hline \multicolumn{7}{|c|}{1997 Landsat - 2016 RapidEye } \\
\hline Gdańsk & Sopot & Gdynia & Kosakowo & Stegna & Sulęczyno & $\begin{array}{c}\text { Nowy Dwór } \\
\text { Gdański }\end{array}$ \\
\hline Land & {$[\%]$} & {$[\%]$} & {$[\%]$} & {$[\%]$} & {$[\%]$} & {$[\%]$} & {$[\%]$} \\
\hline Forests & -7 & -6 & 0 & -4 & 1 & 4 & -2 \\
\hline $\begin{array}{l}\text { Dispersed } \\
\text { development }\end{array}$ & 2 & 3 & 1 & 2 & 2 & 2 & 1 \\
\hline $\begin{array}{l}\text { Compact } \\
\text { development }\end{array}$ & 2 & 1 & 1 & 1 & 0 & 0 & 2 \\
\hline Grassland & 14 & 3 & 6 & 28 & 11 & 18 & 13 \\
\hline Arable land & -9 & -1 & -7 & -26 & -14 & -22 & -14 \\
\hline Water & -2 & 0 & -1 & -1 & 0 & -2 & 0 \\
\hline
\end{tabular}




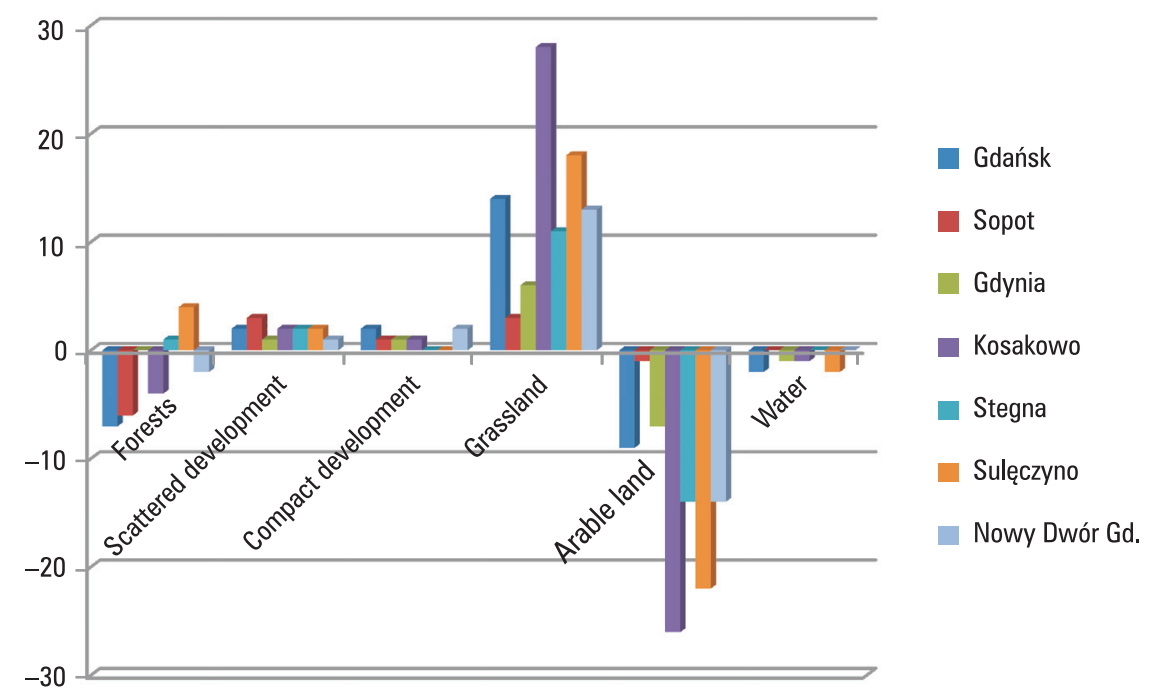

Fig. 9. Chart of percentage changes in land use for individual communes of the Tri-City MA over 20 years

The conducted analysis showed the greatest changes in the way of use in communes with a low Agricultural Production Space Valuation Ratio (APSVR), i.e., in Kosakowo and Sulęczyn. In these communes there was a significant loss of arable land (even of $26 \%$ ) in favor of grassland, and it is independent of the location of these communes in relation to the MA core. In communes with favourable conditions for agricultural production space, these changes are almost half as small.

This relationship is consistent with the law of economic rents (differential rent I). It is also emphasised in the literature on the subject that land with lower suitability for agricultural production is excluded from agricultural use as first [Gellrich and Zimmermann 2007, Xie et al. 2014, Wojewodzic 2017]. The research also showed large changes in the area of grassland, and they were strongly correlated with changes in arable land. The increase of the grassland area took place at the expense of arable land. In most of the analysed communes, the more intensive production on arable land was transformed into a less intensive one based on the use of grassland.

In individual communes and cities, the increase in built-up areas did not exceed $4 \%$, so it is relatively small.

In Gdańsk, Sopot and Gdynia, belonging to the Tri-City, the greatest changes over 20 years took place in arable land, which altogether diminished by $17 \%$, and forest land (13\% in total). All this to the benefit of grassland (increase by $23 \%$ ) and built-up areas (10\% in total in all cities).

The nature of changes in land use for this metropolitan area results primarily from its geographical location and the specificity of industry (the shipbuilding industry predominates here), and tourism has a dominant influence here. 


\section{Conclusions and summary}

The aim of the study was to diagnose the main trends of land cover changes in a selected metropolitan area in Poland. The analyses focused mainly on the assessment of changes in the share of arable land and grassland. The conducted analyses showed that by far the greatest changes took place in communes with worse natural conditions, and not in the MA's core. In the case of this particular metropolitan area, the claim that the strong pressure of the non-agricultural sector in cities reduces the share of arable land mainly in communes close to the city was not confirmed. However, it should be noted that the natural conditions of agricultural activity were of greater importance in the processes of arable land conversion. Larger losses of arable land were recorded in communes with worse conditions for agricultural activity.

The progressive reduction in the intensity of agricultural activity is typical for the areas of fragmented agriculture and is particularly relevant in communes with an attractive labour market. The growing share of grassland with a simultaneous decline in livestock production may, however, be a symptom of speculative activity. The owners of agricultural land do not want to sell or lease them, as having land relatively close to the city may bring benefits in the form of planning rent or location rent [Kwoczyńska et al. 2019].

Research conducted with the support of the National Science Centre under the project No. 2016/21/D/HS4/00264.

\section{References}

Abburu S., Golla S.B. 2015. Satellite Image Classification Methods and Techniques: a Review. International Journal of Computer Applications, 119, 8, 20-25.

Bałazy R., Brach M., Bruchwald A., Choromański A., Dmyterko E., Grzegorzewicz T., Kyc P., Łabaj A., Majsterkiewicz K., Neroj B., Okła K., Olenderek H., Olenderek T., Prengel J., Talarczyk A., Wasiak A., Wężyk P., Wiśniewska E., Witosza W., Zajączkowski G. 2013. Geomatyka w Lasach Państwowych. Część II. Poradnik praktyczny. CILP, Warszawa, 390 .

Barredo J.I., Lavalle C., Demicheli L., Kasanko M., McCormick N. 2003. Sustainable urban and regional planning: The MOLAND activities on urban scenario modelling and forecast. European Commision. Joint Reseach Centre, Institute for Environment and Sustainability. Office for Official Publications of the European Communities, Luxembourg.

Bochenek Z. 2004. Zastosowanie różnych metod określania zmian pokrycia terenu na obszarach miejskich z wykorzystaniem zdjęć satelitarnych. Archiwum Fotogrametrii, Kartografii i Teledetekcji, 14, 1-13.

Brahabhatt V.S., Dalwadi G.B., Chhabra S.B., Ray S.S., Dadhwal V.K. 2000. Landuse/land cover changes mapping in Mahi canal command area, Gujarat, using multi-temporal satellite data, J. Indian Soc. Remote Sensing, 28(4), 221-232.

Bruzzone L., Serpico S.B. 1997. An iterative technique for the detection of land-cover transitions in multitemporal remote-sensing images. IEEE Trans. Geosci. Remote Sens., 35, 858-867.

Busko M., Szafranska B. 2018. Analysis of Changes in Land Use Patterns Pursuant to the Conversion of Agricultural Land to Non-Agricultural Use in the Context of the Sustainable Development of the Malopolska Region. Sustainability, 10, 136. 
Butenuth M., Gösseln G.V., Tiedge M. et al. 2007. Integration of heterogeneous geospatial data in a federated database. ISPRS Journal of Photogrammetry and Remote Sensing, 62(5), 328-346.

Cakir H.I., Khorram S., Nelson S.A.C. 2006. Correspondence analysis for detecting land cover change. Remote Sens. Environ., 102, 306-317.

Cegielska K., Noszczyk T., Kukulska A., Szylar M., Hernik J., Dixon-Gough R., Jombach S., Valánszki I., Filepné Kovács K. 2018. Land use and land cover changes in post-socialist countries: Some observations from Hungary and Poland. Land Use Policy, 78, 1-18.

Chen J., Gong P., He C., Pu R., Shi P. 2003. Land-Use/Land Cover Change Detection Using Improved Change-Vector Analysis. Photogrammetric Engineering \& Remote Sensing, 69, 4, 369-379.

Ciołkosz A., Poławski Z.F. 2006. Zmiany użytkowania ziemi w Polsce w drugiej połowie XX wieku. Przegląd Geograficzny, 78, 2, 173-190.

Civco D.L., Hurd J.D., Wilson E.H., Song M., Zhang Z. 2002. A comparison of land use and land cover change detection methods. ASPRS-ACSM Annual Conference and FIG XXII Congress.

Comber A., Balzter H., Cole B., Johnson S., Oguto B., Fisher P. 2016. Methods to quantify regional differences in land cover change. Remote Sens., 8, 176.

Drzewiecki W. 2008. Monitoring zmian pokrycia i użytkowania terenu na podstawie wieloczasowych obrazów teledetekcyjnych. Rocz. Geomatyki, 6, 131-142.

Gautam N.C., Narayanan L.R.A. 1983. Landsat MSS data for land use/land cover inventory and mapping: A case study of Andhra Pradesh. J. IndianSoc, Remote Sensing, 11(3), 15-28.

Gellrich M., Zimmermann N.E. 2007. Investigating the regional-scale pattern of agricultural land abandonment in the Swiss mountains: A spatial statistical modelling approach. Landsc. Urban Plan., 79, 65-76.

Grabska E. 2017. Ocena możliwości wykorzystania satelitarnych danych optycznych i radarowych do identyfikacji typów użytków rolnych. Prace Geograficzne, 148. Wydawnictwo Uniwersytetu Jagiellońskiego, Kraków, 2017.

Hejmanowska B., Wężyk P. 2020. Dane satelitarne dla administracji publicznej. Polska Agencja Kosmiczna.

Hermosilla T., Wulder M.A., White J.C., Coops N.C., Hobart G.W. 2018. Disturbance-Informed Annual Land Cover Classification Maps of Canada's Forested Ecosystems for a 29Year Landsat Time Series. Can. J. Remote Sens., 44, 1-21.

Jain S.K. 1992. Land use mapping of Tawi catchment using satellite data. Report No.CS72. National Institute of Hydrology, Roorkee, 52.

Krischke M., Niemeyer W., Scherer S. 2000. RapidEye satellite based geo-information system. Acta Astronautica, 46, 307-312. KPZK, 2030.

http://www.wzs.wzp.pl/sites/default/files/files/19683/89272000_1412985316_Koncepcja_Przestrzennego_Zagospodarowania_Kraju_2030.pdf

Kwoczyńska B., Sroka W., Sikora K. 2019. Analysis of land use changes in selected communes of the Lublin metropolitan area based on remote sensing data. Geomatics, Landmanagement and Landscape, 4, 73-91. http://dx.doi.org/10.15576/GLL/2019.4.73

Li X., Yeh A.G.O. 1998. Principal component analysis of stacked multi-temporal images for the monitoring of rapid urban expansion in the Pearl River Delta. Int. J. Remote Sens., 19(8), 1501-1518.

Loveland T.R., Dwyer J.L. 2012. LANDSAT: Building a strong future. Remote Sens. Environ., $122,22-29$. 
Lu D., Mausel P., Brondizio E., Moran E. 2004. Change detection techniques. Int. J. Remote Sens., 25, 12, 2365-2401.

Markham B.L., Helder D.L. 2012. Forty-year calibrated record of earth-reflected radiance from LANDSAT: A review. Remote Sens. Environ., 122, 30-40.

Meliadis I.M. 2005. Correlations of environmental parameters with the use of satellite technology and G.I.S. Forest Research, 17, 19-26 (in Greek).

Meliadis I.M., Tsiontsis A., Daskalakis T. 2005. Estimation of the risk erosion in the soil of the county of Thessaloniki Proceedings of the 12th National Forestry Conference, Forest \& Water Protection of the Environment. Drama 2-5 October, 433-440 (in Greek).

Michałowska K., Głowienka-Mikrut E. 2010. Wieloczasowe dane obrazowe w badaniu zmian pokrycia terenu. Archiwum Fotogrametrii, Kartografii i Teledetekcji, 21, 281-289.

Mularz S., Drzewiecki W., Pirowski T. 2007. Teledetekcyjne metody rejestracji krajobrazu. Roczniki Geomatyki, V, 8.

Niedzielko J., Lewiński S. 2012. Detekcja zmian pokrycia terenu na zdjęciach satelitarnych Landsat - porównanie trzech metod. Teledetekcja Środowiska, 47, 87-98.

Oliveira Duarte D., Zanetti J., Gripp J., Graças Medeiros N. 2016. Comparison of supervised classification methods of Maximum Likelihood image. Minimum Distance, Parallelepiped and Neural network in images of Unmanned Air Vehicle (UAV) in Viçosa-MG, Civil Engineering Department - Federal University of Viçosa (UFV), Campos do Jordao, 30.11.2016.

Peiman R. 2011. Pre-classification and post-classification change-detection techniques to monitor land-cover and land-use change using multi-temporal Landsat imagery: A case study on Pisa Province in Italy. International Journal of Remote Sensing, 4365-4381, August 2011. https://doi.org/10.1080/01431161.2010.486806

Prakasam C. 2010. Land use and land cover change detection through remote sensing approach: A case study of Kodaikanal taluk, Tamil nadu. International Journal of Geomatics and Geosciences, 1, 2, 150-158.

Sandau R., Brieß K., D’Errico M. 2010. Small satellites for global coverage: Potential limits. ISPRS J. Photogramm. Remote Sens., 65, 492-504.

Sarma V.V.L.N., Murali Krishna G., HemaMalini B., NageswaraRao K. 2001. Landuse/Landcover Change Detection through Remote Sensing and its Climatic Implications in the Godavari Delta Region. Journal of the Indian Society of Remote Sensing, 29, 1, 2.

Schneider A. 2012. Monitoring land cover change in urban and pen-urban areas using dense time stacks of Landsat satellite data and a data mining approach. Remote Sensing of Environment, 124, 689-704, June 2012. DOI: 10.1016 / j.rse.2012.06.006

Tewkesbury A., Comber A., Nicholas J., Tate Peter F. Fisher. 2015. A critical synthesis of remotely sensed optical image change detection techniques. Remote Sensing of Environment. DOI: $10.1016 /$ j.rse.2015.01.006

Tian J., Reinartz P. d'Angelo P., Ehlers M. 2013. Region-based automatic building and forest change detection on Cartosat-1 stereo imagery. ISPRS Journal of Photogrammetry and Remote Sensing, 79, 226-239. May. DOI:10.1016/j.isprsjprs.2013.02.017

Verburg P.H., van de Steeg J., Veldkamp A., Willemen L. 2009. From land cover change to land function dynamics: A major challenge to improve land characterization. J. Environ. Manage., 90, 1327-1335.

Vieira M.A., Formaggio A.R., Rennó C.D. (...), Mello M.P. 2012. Object Based Image Analysis and Data Mining applied to a remotely sensed Landsat time-series to map sugarcane over large areas. Remote Sensing of Environment, August 2012, 123, 553-562. 
Vogelmann J.E., Gallant A.L., Shi H., Zhu Z. 2016. Perspectives on monitoring gradual change across the continuity of Landsat sensors using time-series data. Remote Sens. Environ., 185, 258-270.

Wężyk P., Wójtowicz-Nowakowska A., Pierzchalski M., Mlost J., Szafrańska B. 2013. Mapa zmian pokrycia terenu Małopolski 1986-2011 wykonana w oparciu o klasyfikację obiektową obrazów satelitarnych LANDSAT oraz RapidEye. Archiwum Fotogrametrii, Kartografii i Teledetekcji, 25, 273-284.

Wojewodzic T. 2017. Procesy dywestycji i dezagraryzacji w rolnictwie na obszarach o rozdrobnionej strukturze agrarnej. Zeszyty Naukowe Uniwersytetu Rolniczego im. H. Kołłątaja w Krakowie, 535, seria rozprawy, 412.

Wulder M.A., Masek J.G., Cohen W.B., Loveland T.R., Woodcock C.E. 2012. Opening the archive: How free data has enabled the science and monitoring promise of LANDSAT. Remote Sens. Environ., 122, 2-10.

Wulder M.A., White J.C., Loveland T.R., Woodcock C.E., Belward A.S., Cohen W.B., Fosnight E.A., Shaw J., Masek J.G., Roy D.P. 2016. The global Landsat archive: Status, consolidation, and direction. Remote Sens. Environ., 185, 271-283.

Xie H., Wang P., Yao G. 2014. Exploring the dynamic mechanisms of farmland abandonment based on a spatially explicit economic model for environmental sustainability: A case study in Jiangxi Province, China. Sustainability, 6, 1260-1282.

Xu R., Lin H., Lü Y., Luo Y., Ren Y., Comber A. 2018. A modified change vector approach for quantifying land cover change. Remote Sensing, 10, 1578.

Yuan F., Sawaya K.E., Loeffelholz B.C., Bauer M.E. 2005. Land cover classification and change analysis of the Twin Cities (Minnesota) Metropolitan Area by multitemporal Landsat remote sensing. Remote Sens. Environ., 98, 317-328.

Zhu Z., Woodcock C.E. 2014. Continuous change detection and classification of land cover using all available Landsat data. Remote Sens. Environ., 144, 152-171.

Zhu Z. 2017. Change detection using Landsat time series: A review of frequencies, preprocessing, algorithms, and applications. ISPRS J. Photogramm., 130, 370-384.

Dr inż. Bogusława Kwoczyńska

University of Agriculture in Krakow

Department of Agricultural Land Surveying, Cadastre and Photogrammetry

ul. Balicka 253a, 30-198 Kraków

e-mail: boguslawa.kwoczynska@urk.edu.pl

ORCID: 0000-0001-7230-5397 